\title{
Immunohistochemical localization of basic fibroblast growth factor within the mouse uterus
}

\author{
R. J. Wordinger, A. E. Moss, T. Lockard, D. Gray, I-F. C. Chang and \\ T. L. Jackson
}

Department of Anatomy and Cell Biology, The University of North Texas, Texas College of Osteopathic Medicine, Fort Worth, TX 76107-2690, USA

\begin{abstract}
Summary. Uterine samples were either rapidly frozen in liquid nitrogen or placed in Bouin's fixative. A commercial primary polyclonal antibody made in rabbits against human recombinant basic fibroblast growth factor (bFGF) was used. Western blot analysis indicated that the antibody was specific for bFGF and did not react with acidic FGF. The primary antibody was followed by either goat anti-rabbit immunoglobulin $G$ (IgG) conjugated to the fluorescent phycobiliprotein tracer phycoerythrin or biotinylated goat anti-rabbit IgG and a biotin-avidin-peroxidase complex. Specificity controls using adjacent sections were carried out by (i) substituting normal rabbit sera for the primary antisera, (ii) omitting the primary antisera or (iii) extracting sections with $\mathrm{NaCl}\left(2 \mathrm{~mol}^{-1}\right)$ prior to the immunochemical procedures. No binding of the antibody was observed with any of the specificity control sections. The connective tissue stroma and the basal lamina associated with uterine glandular and surface epithelial layers were positive for bFGF. Localization was not observed within surface or glandular epithelial cells. The basal lamina and endothelial cells associated with blood vessels within the uterus and the smooth muscle cells of the myometrium were positive for bFGF. There were no differences in uterine localization patterns or intensity during the oestrous cycle or after ovariectomy and steroid hormone supplementation. These studies demonstrate the specific localization of bFGF within the mouse uterus.
\end{abstract}

Keywords: basic fibroblast growth factor; mouse

\section{Introduction}

Fibroblast growth factors (FGF) constitute a family of structurally related, biologically active, peptides that have a strong affinity for heparin (Baird et al., 1986; Burgess \& Maciag, 1989; Klagsbrun, 1989; Rifkin \& Moscatelli, 1989). Basic fibroblast growth factor (bFGF) is a single-chain, nonglycosylated, cationic polypeptide with molecular mass of about $18 \mathrm{kDa}$ and pI 9.6 (Shing et al., 1983, 1984). Basic FGF was isolated from bovine pituitary (Gospodarowicz, 1974) and brain (Gospodarowicz et al., 1978) and is mitogenic for a variety of cells derived from mesoderm and neuroectoderm including fibroblasts, endothelial cells and glial cells (Gospodarowicz, 1987); it is also a potent promoter of angiogenesis (Folkman \& Klagsburn, 1987) and a strong stimulator of collagenase and plasminogen activator production (Sato \& Rifkin, 1988; Buckley-Sturrock et al., 1989).

These biological activities suggest that bFGF may potentially be a critical regulatory factor, which may modulate various physiological responses within the uterus, but there is little information concerning its presence within these tissues. Although heparin-binding growth factors have been purified and characterized from porcine (Brigstock et al., 1990) and bovine (Milner et al., 1989) uteri, the immunolocalization of specific members of the fibroblast growth factor family within the uterus has not been previously reported. 
The objective of this study was (i) to use light microscopy immunohistochemistry to localize bFGF specifically within the mouse uterus and (ii) to determine whether the localization of bFGF within the uterus is influenced by the stage of the oestrous cycle or by ovariectomy and steroid hormone supplementation.

\section{Materials and Methods}

\section{Animals}

Adult female outbred CD-1 mice were purchased at 6-8 weeks of age from Charles River Laboratories, Inc. (Wilmington, MA, USA). Animals were housed in modern facilities under a controlled photoperiod of $14 \mathrm{~h} \mathrm{light:10 \textrm {h }}$ dark (lights on at $06: 00 \mathrm{~h}$ ) with food and water available ad libitum and at $22^{\circ} \mathrm{C}$.

\section{Ovulatory cycle}

Female mice were examined daily by vaginal lavage to determine the stage of the ovulatory cycle. Six representative animals in oestrus, metoestrus, dioestrus and proestrus were killed by cervical dislocation. The uterine horns and oviducts were dissected and tissues prepared for immunohistochemical localization of bFGF.

\section{Ovariectomy and hormone supplementation}

Bilateral ovariectomy was performed on mice under general anaesthesia (Metofane: Pittman-Moore Inc., Washington Crossing, NJ, USA) by a dorsal-lateral approach. Through a small incision, the ovary was exposed and gently excised with a pair of iridectomy scissors. The incision was secured with sutures and the skin with wound clips. Seven to 10 days after ovariectomy, animals were placed on a hormone regimen which had been shown to sensitize the uterus for implantation (Rankin et al., 1979) and deciduoma formation (Wordinger et al., 1986). The regimen included: $0.1 \mathrm{mg}$ oestradiol on days $1-3$, no treatment on days $4-5,6.7 \mathrm{ng}$ oestradiol and $1.0 \mathrm{mg}$ progesterone on days 6-7 and 1.0 mg progesterone on days 8-11. All hormones were given subcutaneously in $0 \cdot 1 \mathrm{ml}$ of corn oil at $09: 00 \mathrm{~h}$. Representative animals were killed by cervical dislocation on days 0, 3, 5, 7 and 11 . Uterine horns were dissected and tissues prepared for immunohistochemical localization of bFGF.

\section{Primary antisera}

This experiment used two primary antibodies against bFGF: one (donated by Andrew Baird, Whittier Institute, La Jolla, CA, USA) is a polyclonal antibody raised against the 1-24 synthetic fragment of bovine bFGF in which the antigen sequence has only low homology with known FGF-like oncogene products and whose specificity has been reported (Gonzalez et al., 1990). The second antibody was commercially available and was made in rabbits against human recombinant bFGF (Biomedical Technologies, Inc., Stoughton, MA, USA). Western blotting techniques were used and, this antibody did not crossreact with human recombinant acid FGF (aFGF). Human recombinant bFGF and human recombinant aFGF ( $300 \mathrm{ng}$, Biomedical Technologies, Inc.) were separated by electrophoresis on sodium dodecyl sulphate-15\% polyacrylamide gel and transferred to a polyvinylidene difluoride membrane (Immobilon-P, Millipore). The membrane was incubated in blocking buffer $(10 \%$ fetal bovine serum in $2.5 \%$ bovine serum albumin and phosphate-buffered saline (BSA/PBS) for $4 \mathrm{~h}$, rinsed five times in PBS ( $5 \mathrm{~min}$ per rinse) and then incubated with the primary antibody $\left(10 \mu \mathrm{g}\right.$ anti-bFGF ml ${ }^{-1}$ in $\left.2.5 \% \mathrm{BSA} / \mathrm{PBS}\right)$ for $3 \mathrm{~h}$. The sheet was rinsed five times in PBS (3 min per rinse) and incubated with a biotin/avidin system (Vectastain ABC system, peroxidase, rabbit IgG: Vector Laboratories, Burlingame, California) according to instructions with the kit. The sheet was again rinsed in PBS five times ( 3 min per rinse) and developed with $0.05 \%$ 4-chloro-l-napthol, $0.01 \% \mathrm{H}_{2} \mathrm{O}_{2}$ in PBS for $30 \mathrm{~s}$. Development was stopped by rinsing in water.

\section{Immunofluorescent localization of bFGF}

All tissues were rapidly frozen in liquid nitrogen, mounted on stubs and sectioned frozen $\left(-20^{\circ} \mathrm{C}\right)$ at $10 \mathrm{~mm}$. Sections were allowed to air dry at room temperature before fixation in cold $\left(4^{\circ} \mathrm{C}\right)$ absolute methanol for $10 \mathrm{~min}$. After fixation in methanol, tissue sections were rinsed in PBS (three times for $2 \mathrm{~min}$ ) and then incubated in $1 \%$ goat serum (J. R. Scientific, Woodland, CA, USA) in PBS for $30 \mathrm{~min}$ to reduce nonspecific staining. The tissue sections were subsequently incubated overnight $(20 \mathrm{~h})$ at $4^{\circ} \mathrm{C}$ with rabbit anti-human recombinant bFGF (Biomedical Technologies Inc., Stoughton, MA, USA; $12.5 \mathrm{mg} \mathrm{ml} \mathrm{')} \mathrm{in} \mathrm{1 \%} \mathrm{BSA} \mathrm{in} \mathrm{PBS.} \mathrm{After} \mathrm{rinsing} \mathrm{in} \mathrm{PBS} \mathrm{(three} \mathrm{times} \mathrm{for} 5 \mathrm{~min}$ ), tissue sections were incubated with a 1:35 dilution of goat anti-rabbit IgG conjugated to the phycobiliprotein phycoerythrin 


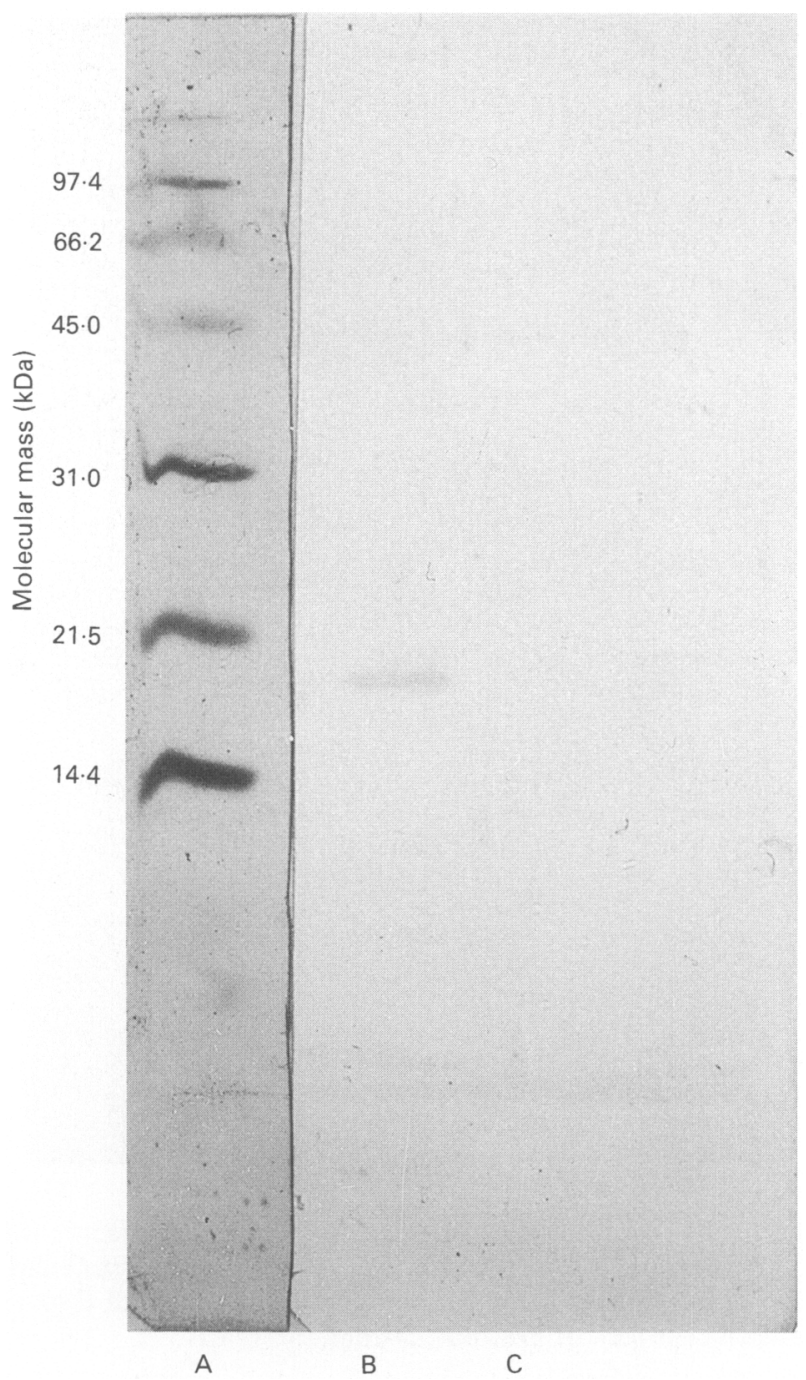

Fig. 1. Western blot of human acidic fibroblast growth factor (FGF) and human basic FGF using anti-human recombinant basic FGF and the Vectastain ABC kit. Lane A, standards of low molecular mass (Sigma Chemical Co.) ranging from 14.4 to $97.4 \mathrm{kDa}$ were stained with Coomassie R-250; lane B, human basic FGF; lane C, human acidic FGF. The commercial primary antibody exhibited no crossreactivity with acidic FGF.

(Biomeda Corp., Forster City, CA, USA) for $1 \mathrm{~h}$. After washing in PBS, FluorSave (Calbiochem, La Jolla, CA, USA), aqueous mounting medium was used to preserve fluorescent-stained tissue sections. All sections were subsequently examined with a Zeiss Photomicroscope III equipped for epifluorescence. Photomicrographs were recorded on T-Max p3200 professional film (Eastman Kodak Co., Rochester, NY, USA).

The choice of an immunoconjugate using the phycobiliprotein phycoerythrin (PE) was based on its higher sensitivity and the propensity for fluorescein to bind nonspecifically to surfaces (Oi et al., 1982; Glazer \& Stryer, 1984). Our initial attempt to localize bFGF within uterine tissues using fluorescein-conjugated goat anti-rabbit IgG as the secondary antibody was unsuccessful because of high nonspecific staining of the conjugate (data not shown).

\section{Immunoperoxidase localization of bFGF}

The technique of Gonzalez et al. (1990) was used. After fixation in Bouin's solution, uterine samples were washed in a graded series of ethanol, embedded in paraffin and sectioned at $8 \mu \mathrm{m}$ on a rotary microtome. Slides were 


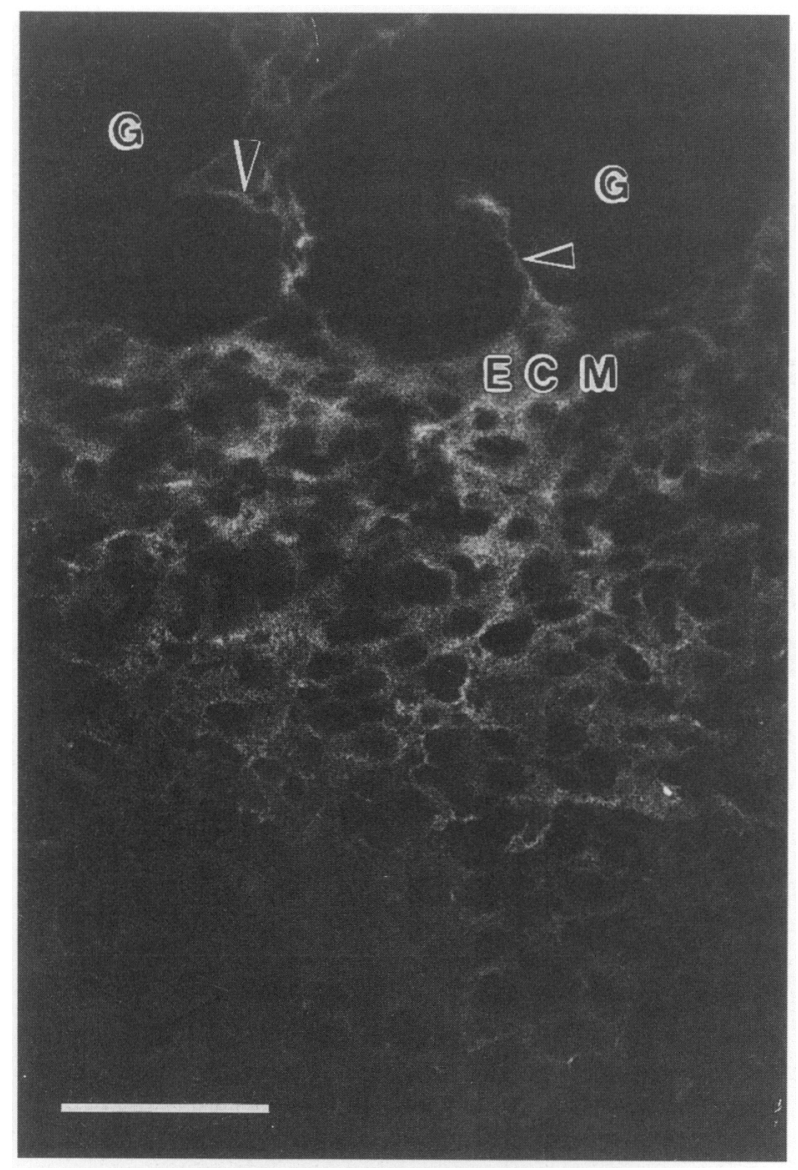

Fig. 2. Immunofluorescent localization of basic fibroblast growth factor (bFGF) within the mouse endometrium: bFGF is localized within the extracellular matrix (ECM) as well as within the basal lamina associated with the uterine glandular epithelial cells (arrowheads); the glandular $(\mathrm{G})$ epithelial cells lack bFGF. Bar: $50 \mathrm{~mm}$.

previously treated with Vectabond (Vector Laboratories. Burlingame. CA, USA) a nonprotein tissue-section adhesive to prevent sections from detaching from the glass. Sections were deparaffinized and hydrated and endogenous peroxidase activity was quenched by incubating the sections in $0.3 \%$ hydrogen peroxide in absolute methanol for 30 min. The penctration of the antibody into the tissue was facilitated by incubating the sections with $1 \mathrm{mg}$ type $\mathrm{V}$ hyaluronidase $\mathrm{ml}$ ' (Sigma Chemical Co. St Louis, MO, USA) buffered at $\mathrm{pH} 5.5$ with $0.1 \mathrm{~mol}$ sodium acetate I ' containing $0.15 \mathrm{~mol} \mathrm{NaCl}{ }^{\prime}$ ', for $30 \mathrm{~min}$ at $37 \mathrm{C}$. Subsequently, tissue sections were incubated with $1.5 \%$ goat serum for $30 \mathrm{~min}$ to reduce nonspecific staining.

Tissue sections were incubated overnight in a moist chamber at 4 ( with the primary antibody at $12.5 \mathrm{mg} \mathrm{ml}$ diluted in PBS supplemented with $0.3 \%$ Triton and 5\% BSA. The sections were then incubated with a 1:200 dilution of biotinylated goat anti-rabbit $\operatorname{IgG}$ (Vector Laboratories. Inc.) for $1 \mathrm{~h}$ followed by a 30 min exposure with biotin avidin-peroxidase complex (Vector Laboratories, Inc.). The sections were treated for $5 \mathrm{~min}$ in $0.5 \mathrm{mg}$ diaminobenzidine $\mathrm{ml}$ ' prepared in $0.1 \mathrm{mmol}$ tris-buffered saline $\mathrm{I}^{\prime}(\mathrm{pH} 7.6$ ) containing $0.01 \%$ hydrogen peroxide. All the individual steps were followed by three buffer washes ( 5 min each wash) consisting of PBS- $0 \cdot 3 \%$ Triton. All sections were then counterstained with Harris haematoxylin, dehydrated, cleared, mounted with Permount (Fisher Scientific Co., Pittsburgh, PA) and examined on a Zeiss Photo III microscope. Photomicrographs were recorded on Pan-X film (Eastman Kodak Co., Rochester, NY) using a green interference filter to increase contrast or Ektachrome 64T for colour slides. 


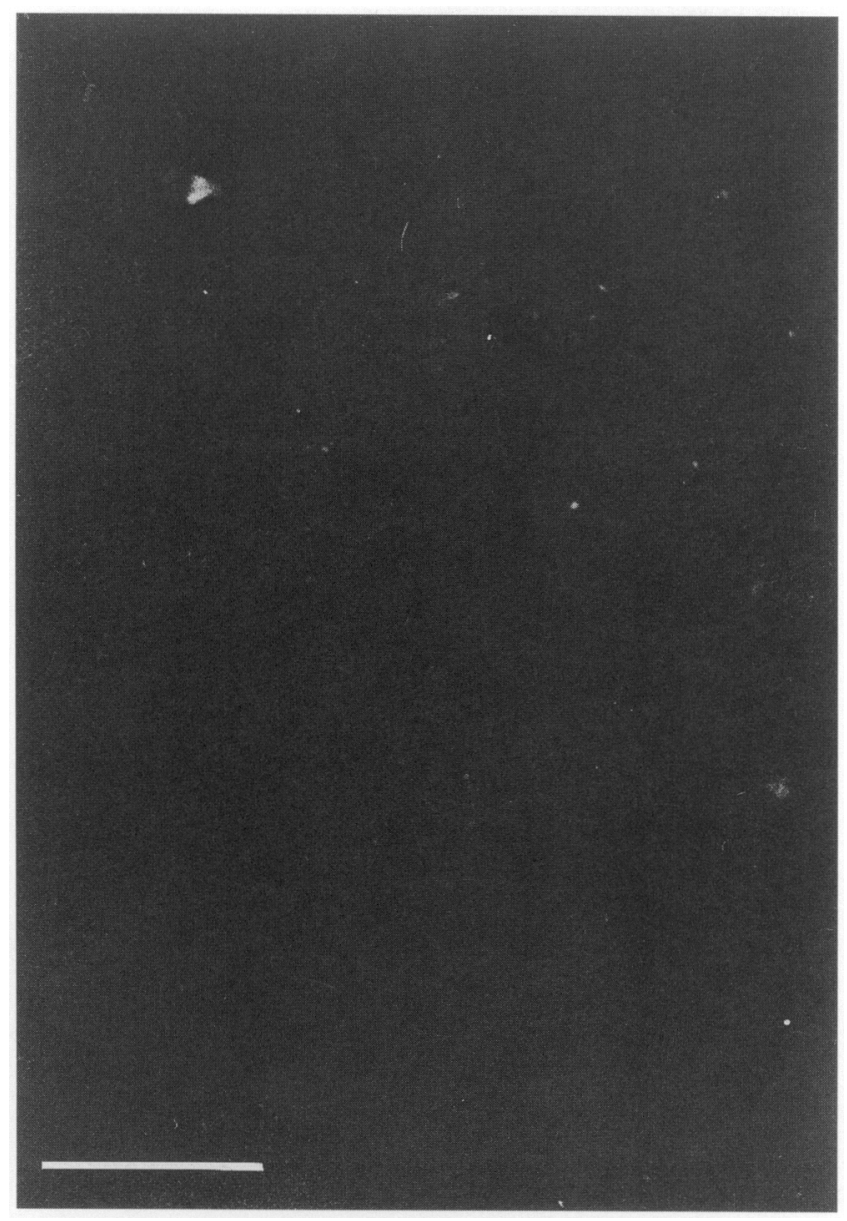

Fig. 3. Immunofluorescent control slide of mouse endometrium. Tissue section was extracted with $2.0 \mathrm{~mol} \mathrm{NaCll}$ ' before staining; there are no reactive areas. Bar: $50 \mathrm{~mm}$.

\section{Results}

\section{Specificity of the immunohistochemical localization of bFGF}

Western blot analysis indicated that the commercial antibody recognized only the $18 \mathrm{kDa}$ bFGF and did not crossreact with aFGF (Fig. 1). The specificity of the technique was further assessed by (i) incubating tissue sections with goat anti-rabbit IgG conjugated to PE or biotin in the absence of the primary antisera, which examines the identification of nonspecific adsorption of the second antibody to the tissue sections; (ii) incubating tissue sections in pooled rabbit sera followed by goat anti-rabbit IgG-PE or biotinylated goat anti-rabbit IgG. which examines nonspecific binding of IgG to the tissue sections; and (iii) extraction of tissue sections with $2.0 \mathrm{~mol}$ $\mathrm{NaCl}{ }^{1}$ for $60 \mathrm{~min}$ at $37 \mathrm{C}$, which removes extracellular bFGF (Gonzalez et al., 1990). There was a lack of staining in all control sections examined. Nonspecific binding of avidin to mast-cell granules was not observed using the biotin-avidin-peroxidase complex. A previous report had indicated that avidin conjugated to peroxidase or fluorescein binds to mast-cell granules (Tharp et al., 1985). 


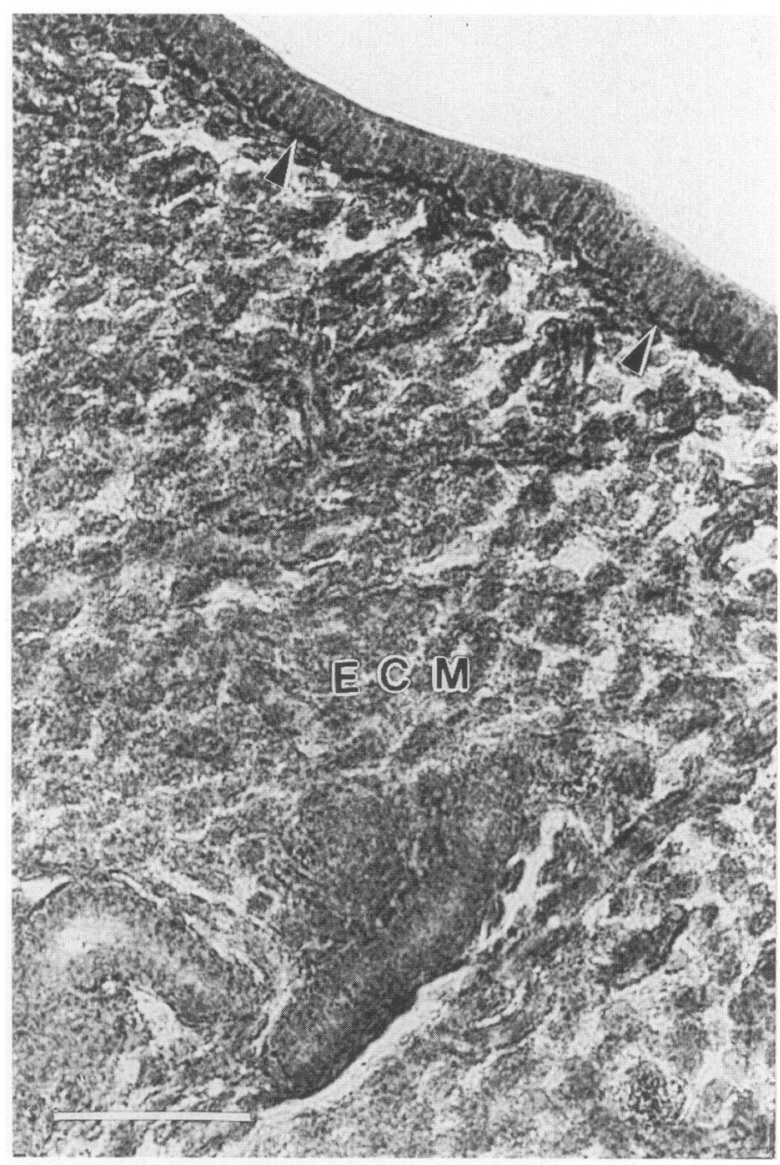

Fig. 4. Immunoperoxidase localization of bFGF within the mouse endometrium. There is intense reactivity within the basal lamina associated with the lumen surface epithelial layer (arrowheads) and a diffuse reaction within the extracellular matrix (ECM). Harris haematoxylin counterstain. Bar: $50 \mathrm{~mm}$.

\section{Comparison of antibodies}

The commerical antibody raised in rabbits against human recombinant bFGF and the donated antisera raised in rabbits against amino acids 1-24 of the synthetic fragment of bovine bFGF resulted in identical localization patterns in this study.

\section{Immunohistochemical localization of bFGF in the uterus}

Both immunofluorescent and immunoperoxidase localization techniques demonstrated the presence of bFGF within the uterus. Within the endometrium, the extracellular matrix was positive for bFGF localization (Fig. 2). The basal laminae underlying the endometrial luminal (Fig. 4) and glandular (Fig. 5) epithelial cell layers were highly reactive, but the glandular and surface epithelial cells lacked bFGF. Both immunofluorescent (Fig. 2) and immunoperoxidase (Fig. 6) control slides (Fig. 3) were negative for immunolocalization of bFGF.

The basal laminae and endothelial cells associated with vascular elements throughout the uterus were reactive (Fig. 7). Staining was also observed within the myofibrils of arteries (Figs 7 and 8). Within the myometrium, the inner circular and outer longitudinal smooth-muscle layers were 


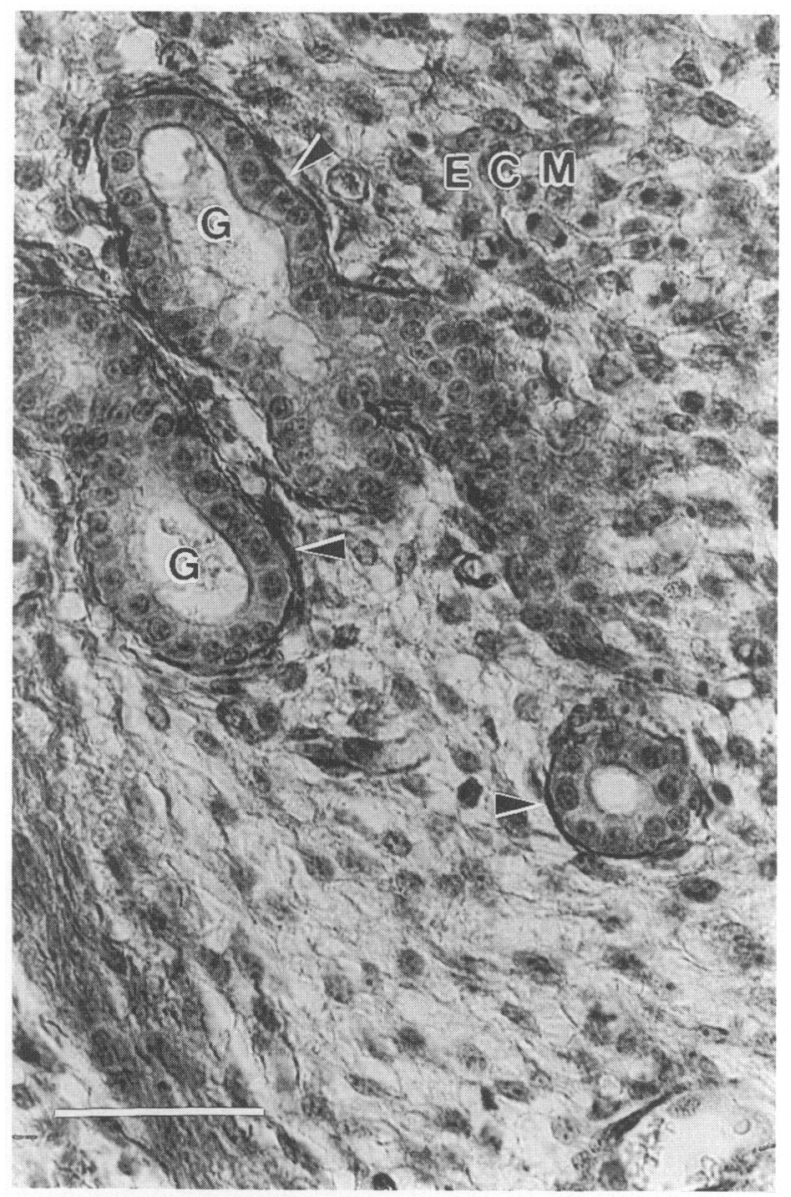

Fig. 5. Immunoperoxidase localization of bFGF within the mouse endometrium. There is an intense localization associated with the basal lamina of the endometrial glandular epithelial layer (arrows) as well as a diffuse reaction in the extracellular matrix (ECM). Harris haematoxylin counterstain. G: uterine glands. Bar: $50 \mathrm{~mm}$.

highly reactive (Figs 7 and 8 ). Control slides revealed no staining within any myometrial components (Figs 3 and 6). The extracellular matrix of the perimetrium was also positive for bFGF as was the basal lamina associated with the mesothelial covering of the uterus.

\section{Influence of the oestrous cycle on the immunolocalization of bFGF in the uterus}

Uterine tissue sections were examined for bFGF localization by the immunofluorescent technique. Tissue samples were obtained at oestrus, dioestrus, metoestrus and proestrus. There was little if any variation in bFGF staining intensity or localization pattern within the uterus during the oestrous cycle. Basic FGF was localized in the extracellular matrices including the basal laminae and the smooth-muscle layers exhibited identical localization patterns to that described above.

Influence of ovariectomy and steroid hormone supplementation on the immunolocalization of bFGF in the uterus

Uterine tissue sections were examined for bFGF localization by the immunofluorescent technique. Tissue samples were examined on days $0,3,5,7$ and 11 after ovariectomy and steroid 


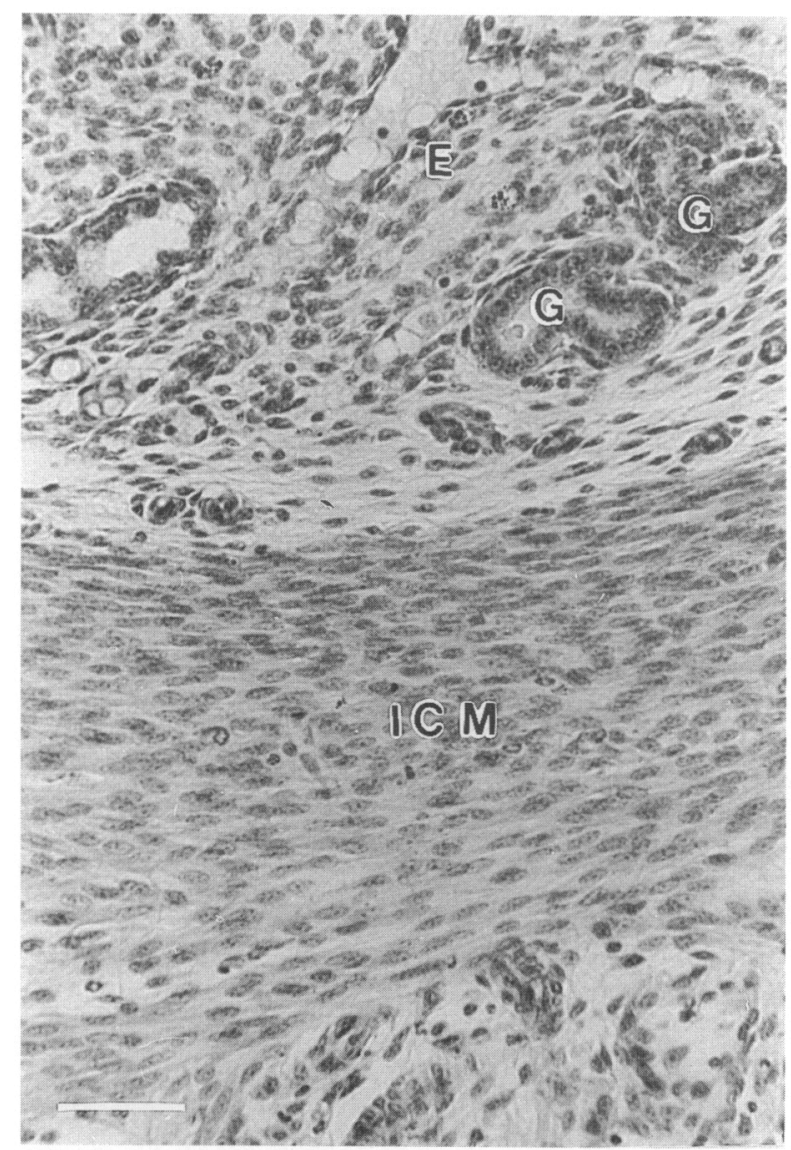

Fig. 6. Immunofluorescent control preparation. There is a lack of fluorescent reaction within the mouse endometrium. Tissue section was extracted with $2.0 \mathrm{~mol} \mathrm{NaCl} 1^{-1}$ before incubation with primary antibody. E: endometrium; G: uterine glands; ICM: inner circular muscle layer. Bar: $50 \mathrm{~mm}$.

hormone supplementation. These days correspond to ovariectomy without hormone treatment (day 0), oestradiol alone (day 3), oestradiol and progesterone (day 5), and progesterone alone (days 7 and 11), respectively. There was little if any variation in the localization of bFGF after ovariectomy and steroid hormone supplementation; bFGF was localized in the extracellular matrices including the basal laminae and the smooth-muscle layers of the myometrium exhibited identical localization patterns to that described above.

\section{Discussion}

Basic FGF is a member of a family of polypeptides characterized by their wide distribution in tissues and their ability to modulate cell proliferation, differentiation and angiogenesis (see Baird $e t$ al., 1986; Gospodarowicz \& Cheng, 1986; Burgess \& Macaig, 1989; Klagsbrun, 1989 for reviews). It has been suggested that bFGF is sequestered in a stabilized form within the extracellular matrix (Baird \& Ling, 1987; Folkman et al., 1988; Vlodavsky et al., 1987; Baird \& Walicke, 1989. Our results are in agreement with this suggestion, since we demonstrated that the immunolocalization of bFGF within the uterus is within the extracellular matrix including the basal laminae associated with epithelial and endothelial cell layers. We demonstrated the localization of bFGF within 


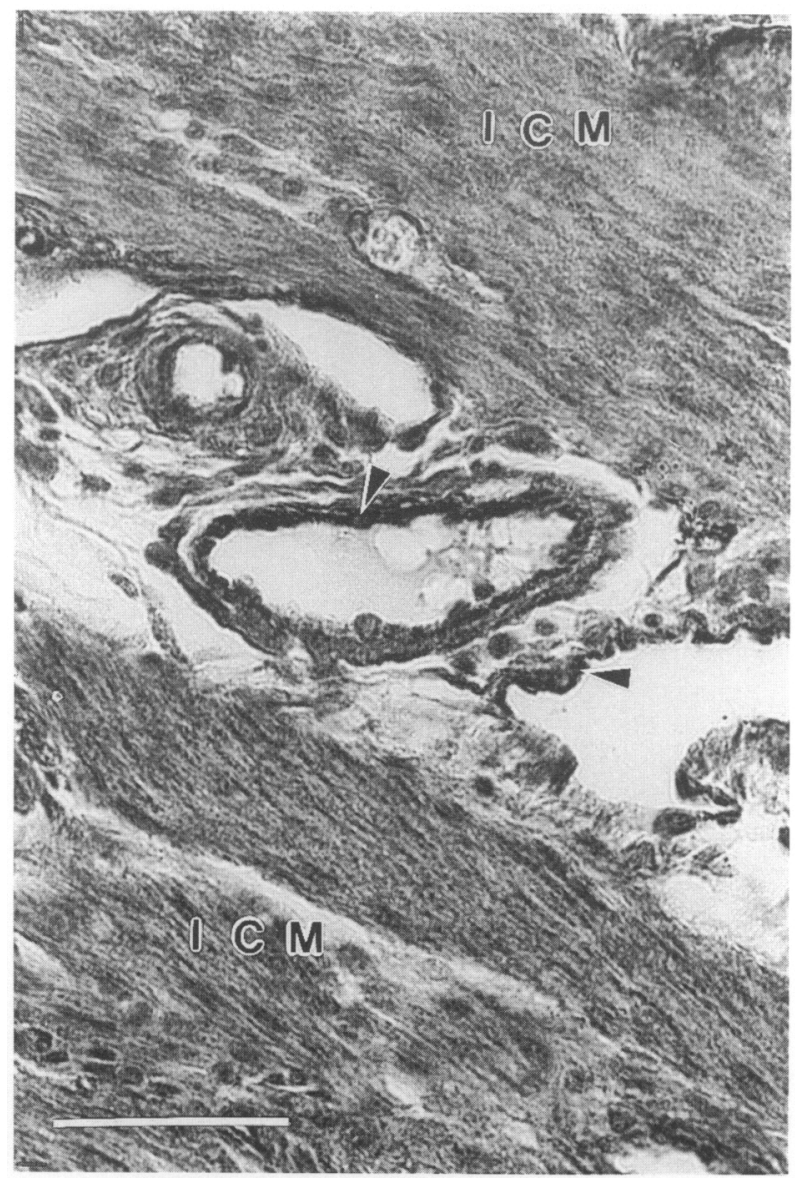

Fig. 7. Immunoperoxidase localization of basic fibroblast growth factor (bFGF) within the mouse myometrium. Note the localization of bFGF within the endothelial cells and basal lamina associated with blood vessels (arrowheads). There is also a diffuse localization within the inner circular smooth muscle layer (ICM) of the myometrium. Bar: $50 \mathrm{~mm}$.

smooth-muscle myofibrils associated with arteries and the myometrium. Although Brigstock et al. (1990) and Milner et al. (1989) characterized and purified heparin-binding growth factors from porcine and bovine uterus, the specific immunohistochemical localization of bFGF within the endometrium and myometrium of the uterus had not been reported.

The cell source and the mechanism by which bFGF reaches the uterine extracellular matrix is not known, since bFGF lacks a signal peptide (Abraham et al., 1986). The bFGF produced by cells appears to remain cell associated or is deposited in the extracellular matrix by an unknown mechanism. Both basic and acidic FGF have a strong affinity for the anionic glycosaminoglycan, heparin (Shing et al., 1983, 1984), which appears to be a stabilizing factor that protects basic and acidic FGF from inactivation by acid and heat (Gospodarowicz \& Cheng, 1986) and degradation by proteases (Sommer \& Rifkin, 1989). These extracellular heparin-like binding sites may be reservoirs that concentrate bFGF in the vicinity of potential target cells (Folkman \& Klagsbrun, 1987).

The ubiquity of fibroblast growth factors in normal adult tissues that are neither growing nor undergoing angiogenesis or differentiation suggests that FGF activity must be highly regulated under normal physiological conditions. Shimasaki et al. (1988) reported that FGF mRNA was below the limits of detection in adrenal gland, spleen, heart, lung, kidney, liver, stomach, small 


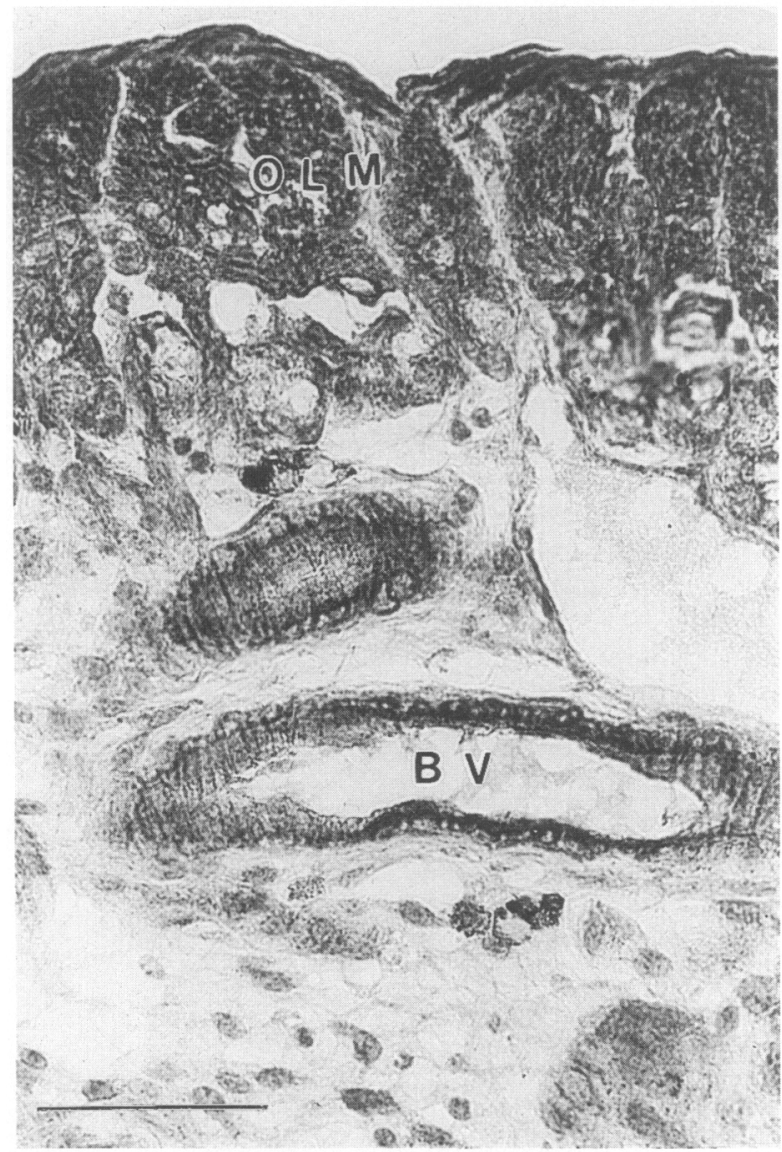

Fig. 8. Immunoperoxidase localization of basic fibroblast growth factor (bFGF) within the mouse myometrium. Note the localization of bFGF within the outer longitudinal smooth muscle layer (OLM) and the blood vessels (BV) in this area. Bar: $50 \mathrm{~mm}$.

intestine and large intestine, despite the high concentrations of FGF found in these tissues. This implies that the bFGF gene is transcribed neither constitutively nor in large amounts, but that its transcription may be induced intermittently when the extracellular storage of bFGF has been depleted. Little is known about the bio-availability of bFGF stored within the extracellular matrix or basal lamina. It is possible that bFGF is stored in the extracellular matrix in a bio-unavailable form and that the regulation of bFGF is at the level of its bio-availability rather than its synthesis (Baird \& Ling, 1987).

Although oestrogen has been studied extensively as a key regulator of uterine cell growth (Murphy \& Ghahary, 1990), it has been suggested that uterine growth factors may also mediate uterine responses (Brigstock et al., 1989; Pollard, 1990). It is possible that the mitogenic effect attributed to oestrogens may be mediated via growth factors synthesized by the uterus in response to steroid hormones (Brigstock, 1991). It has been reported that the uterine expression of insulinlike growth factors I and II (Murphy et al., 1987) and epidermal growth factor (Gonzalez et al., 1984; Di Augustine et al., 1988) is regulated by oestrogens.

Although Presta (1988) has shown that synthesis of bFGF in uterine adenocarcinoma cells was stimulated by oestradiol, no previous studies have examined the regulation of uterine FGF by steroidal hormones in animals. Our studies indicate that there was no influence of the stage of the oestrous cycle or ovariectomy followed by steroid hormone supplementation on bFGF localization 
in the uterine extracellular matrix. Although biologically active endogenous bFGF can be released from the extracellular matrix (Saksela \& Rifkin, 1990), it is probably the result of very localized alterations and would not be reflected by changes in the overall immunolocalization of bFGF at the light microscopy level. Basic FGF probably acts via autocrine or paracrine mechanisms within a limited environment, thus reducing the likelihood of observing large changes in localization patterns. It is more likely that localized changes in bFGF would occur in the uterine extracellular matrix and the various basal laminae during embryo invasion and the initiation of angiogenesis and the decidual cell response. For example, although collagenase does not cleave bFGF or inactivate its biological activity, bFGF could be released when the basal lamina is traumatized or enzymatically degraded by heparinases or other proteases, perhaps during embryo invasion into the extracellular matrix during implantation.

Basic FGF is a member of a family of biologically active polypeptides that are believed to modulate cell proliferation, differentiation and angiogenesis via autocrine and paracrine mechanisms. These functions are potentially critical for various physiological responses within the uterus. We have demonstrated the specific immunolocalization of bFGF in the extracellular matrix of the mouse uterus and we have shown that neither the stage of the oestrous cycle nor ovariectomy and steroid hormone supplementation appear to alter the localization of bFGF within the uterus. We are currently examining whether the localization of bFGF within the uterus is influenced by embryo invasion into the extracellular matrix and decidual cell formation.

We thank A-M. Brun-Zinkernagel for excellent photographic assistance. This study was supported by NIH grant HD-25638.

\section{References}

Abraham, J.A., Mergia, A., Whang, J.L., Tumolo, A., Friedman, J., Hjerrild, K.A., Gospodarowicz, D. \& Fiddes, J.C. (1986) Nucleotide sequence of a bovine clone encoding the angiogenic protein, basic fibroblast growth factor. Science 233, 545-548.

Baird, A. \& Ling, N. (1987) Fibroblast growth factors are present in the extracellular matrix produced by endothelial cells in vitro: implication for a role of heparinase-like enzymes in the neovascular response. Biochemical and Biophysical Research Communications 142, 428-435.

Baird, A. \& Walicke, P.A. (1989) Fibroblast growth factors. British Medical Journal 45, 438-452.

Baird, A., Esch, F., Mormede, P., Ueno, N., Ling, N., Bohlen, P., Ying, S-Y., Wehrenberg, W.B. \& Guillemin, R. (1986) Molecular characterization of fibroblast growth factor: distribution and biological activities in various tissues. Recent Progress in Hormone Research 42, $143-205$.

Brigstock, D.R. (1991) Growth factors in the uterus: steroidal regulation and biological actions. In Baillier's Clinical Endocrinology and Metabolism. 5, 791-808.

Brigstock, D.R., Heap, R.B. \& Brown, K.D. (1989) Polypeptide growth factors in uterine tissues and secretions. Journal of Reproduction and Fertility 85, 747-758.

Brigstock, D.R., Heap, R.B., Barker, P.J. \& Brown, K.D. (1990) Purification and characterization of heparinbinding growth factors from porcine uterus. Biochemical Journal 266, 273-282.

Buckley-Sturrock, A., Woodard, S.C., Senior, R.M., Griffin, G.L., Klagsbrun, M. \& Davidson, J.M. (1989) Differential stimulation of collagenase and chemotactic activity in fibroblasts derived from rat wound repair tissue and human skin by growth factors. Journal of Cell Physiology 138, 70-80.

Burgess, W.H. \& Maciag, T. (1989) The heparinbinding (fibroblast) growth family of proteins Annual Review's of Biochemistry 58, 575-606.

Di Augustine, R.P., Petrusz, P. \& Bell, G.I. (1988) Influence of estrogens on mouse uterine epidermal growth factor precursor protein and messenger ribonucleic acid. Endocrinology 122, 2355-2363.

Folkman, J. \& Klagsbrun, M. (1987) Angiogenic factors Science 235, 442-447.

Folkman, J., Klagsbrun, M., Sasse, J., Wadzinski, M.G., Ingber, D. \& Vlodavsky, I. (1988) A heparin-binding angiogenic protein-basic fibroblast growth factor is stored within basement membrane. American Journal of Pathology 130, 393-400.

Glazer, A.N. \& Stryer, L. (1984) Phycofluor probes. Trends in Biochemical Sciences 9, 423-427.

Gonzalez, F., Lakshmanan, J., Hoath, S. \& Fisher, D.A. (1984) Effect of oestradiol-17 $\beta$ on uterine epidermal growth factor concentration in immature mice. Acta Endocrinologica 105, 425-428.

Gonzalez, A-M., Buscaglia, M., Ong, M. \& Baird, A. (1990) Distribution of basic fibroblast growth factor in the 18-day rat fetus: localization in the basement membranes of diverse tissues. Journal of Cell Biology 110, 753-765.

Gospodarowicz, D. (1974) Purification of a fibroblast growth factor from bovine pituitary. Journal of Biological Chemistry 250, 2515-2520.

Gospodarowicz, D. (1987) Fibroblast growth factor. In Growth and Maturation Factors, pp. 1-36. Ed. G. Guroff. John Wiley and Sons. New York. 
Gospodarowicz, D. \& Cheng, J. (1986) Heparin protects basic and acidic FGF from inactivation. Journal of Cell Physiology 128, 475-484.

Gospodarowicz, D., Bialecki, H. \& Greenberg, G. (1978) Purification of fibroblast growth factor from bovine brain. Journal of Biological Chemistry 253, 3736-3743.

Klagsbrun, M. (1989) The fibroblast growth factor family: structural and biological properties. Progress in Growth Factor Research 1, 207-235.

Milner, P.G., Li, Y-S., Hoffman, R.M., Kodner, C.M., Siegel, N.R. \& Deuel, T.F. (1989) A novel $17 \mathrm{kD}$ heparin-binding growth factor (HBGF-8) in bovine uterus: purification and $N$-terminal amino acid sequence. Biochemical and Biophysical Research Communications 165, 1096-1 103.

Murphy, L.J. \& Ghahary, A. (1990) Uterine insulin-like growth factor-1: regulation of expression and its role in estrogen-induced uterine proliferation. Endocrine Reviews 11, 443-453.

Murphy, L.J., Murphy, L.C. \& Friesen, H.G. (1987) A role for the insulin-like growth factors as estromedins in the rat uterus. Transactions of Association of American Physicians 100, 204-214.

Oi, V.T., Glazer, A.N. \& Stryer, L. (1982) Fluorescent phycobiliprotein conjugates for analyses of cells and molecules. Journal of Cell Biology 93, 981-986.

Pollard, J.W. (1990) Regulation of polypeptide growth factor synthesis and growth factor-related gene expression in the rat and mouse uterus before and after implantation. Journal of Reproduction and Ferility 88, 721-731.

Presta, M. (1988) Sex hormones modulate the synthesis of basic fibroblast growth factor in human endometrial adenocarcinoma cells: implications for the neovascularization of normal and neoplastic endometrium. Journal of Cellular Physiology 137, 593-597.

Rankin, J.C., Ledford, B.E., Jonsson, H.T. \& Baggett, B. (1979) Prostaglandins, indomethacin and the decidual cell reaction in the mouse uterus. Biology of Reproduction 20, 299-304.

Rifkin, D.B. \& Moscatelli, D. (1989) Recent developments in the cell biology of basic fibroblast growth factor. Journal of Cell Biology 109, 1-6.

Saksela, O. \& Rifkin, D.B. (1990) Release of basic fibroblast growth factor-heparin sulfate complexes from endothelial cells by plasminogen activatormediated proteolytic activity. Journal of Cell Biology $110,767-775$.

Sato, Y. \& Rifkin, D.B. (1988) Autocrine activities of basic fibroblast growth factor: regulation of endothelial cell movement, plasminogen activator synthesis and DNA synthesis. Journal of Cell Biology 107, 1129-1205.

Shimasaki, S., Emoto, N., Koba, A., Mercado, M., Shibata, F., Cooksey, K., Baird, A. \& Ling, N. (1988) Complementary DNA cloning and sequencing of rat ovarian basic fibroblast growth factor and tissue distribution study of its mRNA. Biochemical and Biophysical Research Communications 157, $256-263$.

Shing, Y., Folkman, J., Murray, M. \& Klagsbrun, M. (1983) Purification by affinity chromatography on heparin-Sepharose of a growth factor that stimulates capillary endothelial cell proliferation. Journal of Cell Biology 97, 395a.

Shing, Y., Folkman, J., Sullivan, R., Butterfield, C., Murray, J. \& Klagsbrun, M. (1984) Heparin affinity: purification of a tumor-derived capillary endothelial cell growth factor. Science 223, 1296-1299.

Sommer, A. \& Rifkin, D.B. (1989) Interaction of heparin with human basic fibroblast growth factor: protection of the angiogenic protein from proteolytic degradation by glycosaminoglycan. Journal of Cell Physiology 138, 21 5-220.

Tharp, M.D., Seelig, L. L., Jr, Tigelaar, R.E. \& Bergstresser, P.R. (1985) Conjugated avidin binds to mast cell granules. Journal of Histochemistry and Cytochemistry 33, 27-32.

Vlodavsky, I., Folkman, J., Sullivan, R., Fridman, R., Ishai-Michaeli, R., Sasse, J. \& Klagsbrun, M. (1987) Endothelial cell-derived basic fibroblast growth factor: synthesis and deposition into subendothelial extracellular matrix. Proceedings of the National Academy of Sciences USA 84, 2292-2296.

Wordinger, R.J., Jackson, F.L. \& Morrill, A. (1986) Implantation, deciduoma formation and live births in mast cell-deficient mice $\left(W / W^{\prime}\right)$ Journal of Reproduction and Fertility 77, 471-476.

Revised manuscript received 16 April 1992 